\title{
Minimization of Soil Pollution as a Result of the Use of Encapsulated Mineral Fertilizers
}

\section{Serhii Vakal 1*, Anna Yanovska', Viktoriia Vakal', Artem Artyukhov', Viktoriia Shkola', Tetiana Yarova', Valerii Dmitrikov' ${ }^{2}$, Jan Krmela ${ }^{3,4}$, Myroslav Malovanyy ${ }^{5}$}

1 Sumy State University, 2, R.-Korsakov str., 40000, Sumy, Ukraine

2 Poltava State Agrarian Academy, 1/3, Skovoroda str., 36003, Poltava, Ukraine

${ }^{3}$ Faculty of Mechanical Engineering, J. E. Purkyně University in Ustí nad Labem, Pasteurova 3334/7, 40001 Ustí nad Labem. Czech Republic

${ }^{4}$ Faculty of Industrial Technologies in Púchov, Alexander Dubček University of Trenčín, I. Krasku 491/30, 02001 Púchov. Slovak Republic

${ }^{5}$ Lviv Polytechnic National University, 12, Bandera street, 79013, Lviv, Ukraine

* Corresponding author's e-mail: vsvakal@gmail.com

\begin{abstract}
The application of nitrogen fertilizers allows increasing crop yields and partially increase the natural soil fertility. They have a negative influence on the environment due to the significant release of nitrogen. Hence, the technology for decreasing the N-release is proposed in this work. Obtaining of complex organo-mineral NPK fertilizers by encapsulating a carbamide granule with a phosphate-potassium shell with humates is the main aim of this work. The main tasks of this shell is slow release of the nitrogen and phosphate nutrients from the granules into the soil following the agrochemical needs of plants and prevention of soil pollution. The powdered components agglomeration of phosphate and potassium fertilizers with a small amount of liquid phase (plasticizer) allows forming a phosphate-containing coating on a carbamide core by means of the semi-dry method. This innovation allows organizing the production of such a product at the average enterprise with less capital investment. Carbamide prills, phosphate-glauconite concentrate, calcium and potassium ballast humate, and "Avatar" trace-element chelate complex were used in experimental studies. A preliminary assessment of the market prospects for such an innovation shows a high level of market attractiveness for all market participants: producers, consumers, and society.
\end{abstract}

Keywords: phosphates, carbamide, calcium and potassium humates, organo-mineral fertilizers, "Avatar" traceelement complex.

\section{INTRODUCTION}

Contamination of soils and natural landscapes by various wastes, including waste heaps and sludge accumulators (Malovanyy et al., 2020a), landfills (Popovych et al., 2018), and wastewater from municipal and industrial wastewater treatment (Malovanyy et al., 2016), creates significant environmental problems, thereby violating the environmental security in the country, guaranteed by the national and international legislation (Brauweiler et al., 2017). These problems include the contamination of agricultural land with unused plants and nutrients of mineral fertilizers. After all, mineral fertilizers that are applied to the soil are not fully absorbed by plants, some of them enter the environment, polluting the groundwater and surface water.

The intensive agricultural production needs fertilizers, which are one of the main sources of environmental pollutants, soil acidity, and the introduction of potentially dangerous heavy metals into soils. High amounts of N-containing fertilizers, which are necessary during the first vegetation period, can have a negative influence on the environment due to the significant 
release of nitrogen: into the air as a gaseous $\mathrm{N}_{2}$ and groundwater and soils as nitrates (Assessing, 2014; Voloshchuk, 2017).

Hence, they accumulated in agricultural products in excessive amounts. High doses of fertilizers also increase the soil acidity and are sources of environmental pollution with heavy metals (Baliuk, 2012). Due to the increasing of agrogenic load on the environment, the agricultural production needs environmentally friendly fertilizers. It allows enhancing the agronomic and economic efficiency of fertilizers while reducing the negative consequences of their use. A required condition for the agriculture greening is an evolutionary transition to a progressive system of biosphere land use adapted to the environmental conditions.

Currently, the following types of mineral fertilizers are present on the Ukrainian market: nitrogen, phosphate, potassium and complex, which have an advantage in application (Table 1). It should be noted that the dynamics of the exportimport operations (Fig. 1 and Fig. 2) indicates a significant reduction in exports of mineral fertilizers while increasing the volume of their imports.

The analysis of imports and exports in terms of commodity positions shows a significant reduction in the demand for the nitrogen and phosphorus fertilizers of Ukrainian manufacturers in foreign markets while increasing the demand for them in the domestic market. The demand for potassium fertilizers in both foreign and domestic markets had a negative trend. The greatest demand in the domestic market is for complex mineral fertilizers, the import of which has a steady upward trend, whereas the volume of exports of such fertilizers

Table 1. The structure of production and consumption of mineral fertilizers in 2015 (According to the data of the "NIITEKHIM" Cherkasy State Enterprise)

\begin{tabular}{|c|c|c|c|c|c|c|}
\hline \multirow[b]{2}{*}{ Fertilizer name } & \multirow{2}{*}{$\begin{array}{l}\text { Production } \\
\text { volume, } \\
\text { thousand tons }\end{array}$} & \multirow{2}{*}{$\begin{array}{l}\text { Export, } \\
\text { thousand tons }\end{array}$} & \multirow{2}{*}{$\begin{array}{l}\text { Import, } \\
\text { thousand tons }\end{array}$} & \multirow{2}{*}{$\begin{array}{l}\text { Local } \\
\text { consumption, } \\
\text { thousand tons }\end{array}$} & \multicolumn{2}{|c|}{ Internal consumption, \% } \\
\hline & & & & & $\begin{array}{l}\text { Local } \\
\text { products, \% }\end{array}$ & $\begin{array}{l}\text { Imported } \\
\text { products, \% }\end{array}$ \\
\hline $\begin{array}{l}\text { Nitrogen } \\
(100 \% \mathrm{~N})\end{array}$ & 1638.6 & 879.4 & 317.7 & 1076.9 & 70.0 & 30.0 \\
\hline $\begin{array}{c}\text { Phosphate } \\
\left(100 \% \mathrm{P}_{2} \mathrm{O}_{5}\right)\end{array}$ & 2.1 & 0.0 & 2.8 & 4.9 & 43.0 & 57.0 \\
\hline $\begin{array}{c}\text { Potassium } \\
\left(100 \% \mathrm{~K}_{2} \mathrm{O}\right)\end{array}$ & 4.46 & 2.28 & 81.30 & 83.48 & 97.00 & 3.00 \\
\hline $\begin{array}{l}\text { Complex and mixed } \\
\text { (physical quantity) }\end{array}$ & 250.0 & 25.4 & 1200.9 & 1425.5 & 15.8 & 84.2 \\
\hline
\end{tabular}

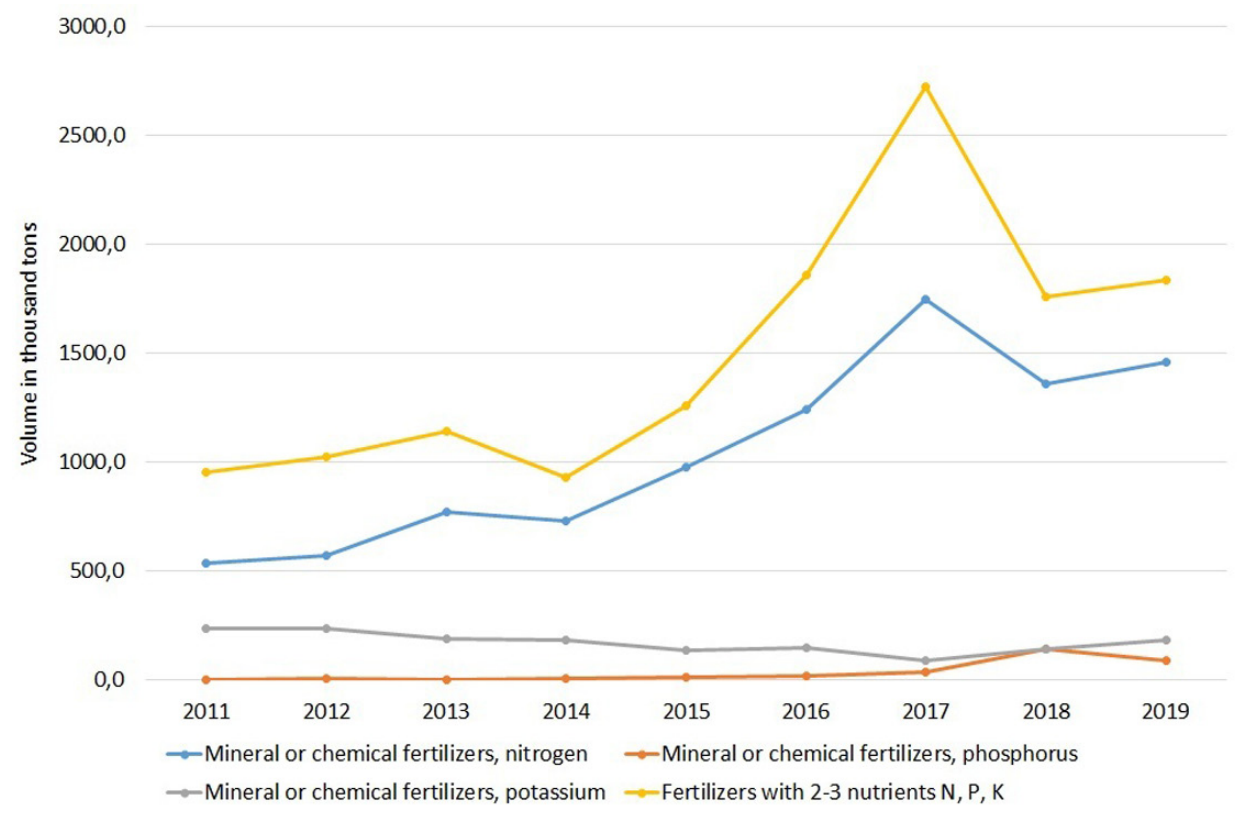

Fig. 1. Import volume of mineral or chemical fertilizers in Ukraine from 2011 to 2019 [Based on (State, 2020a)] 


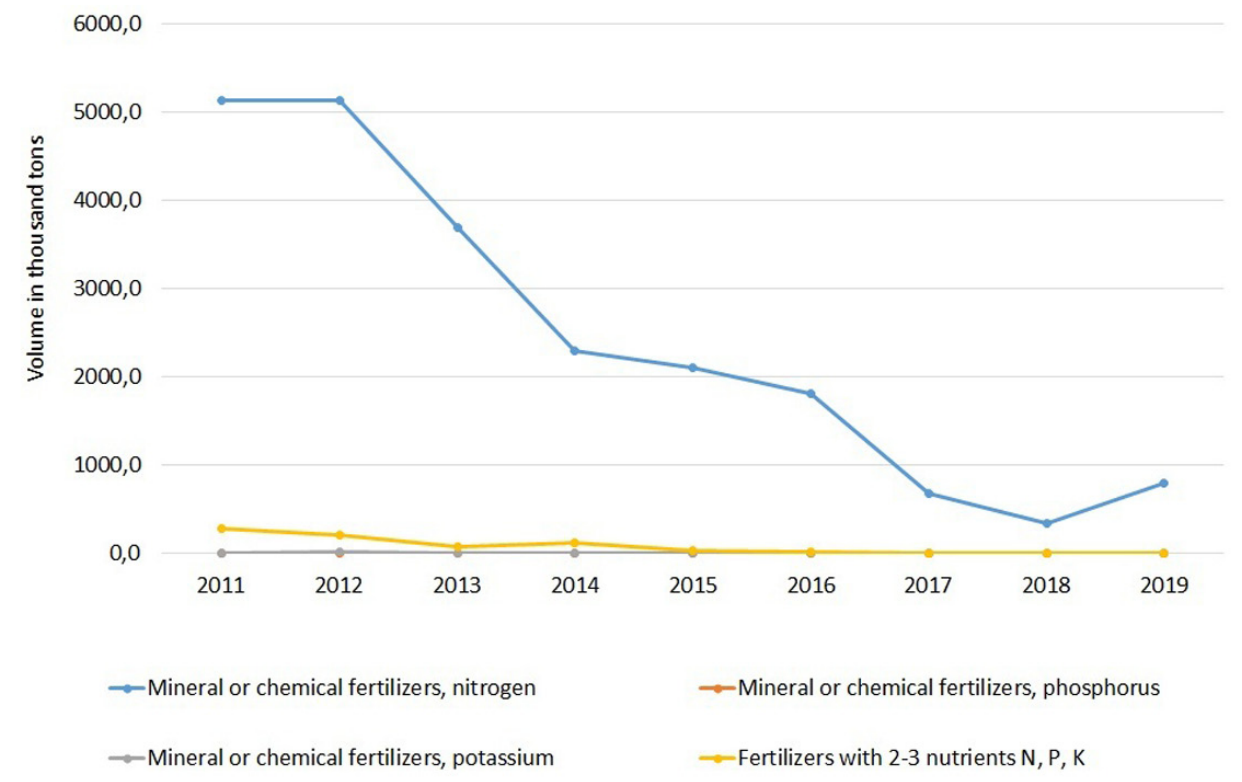

Fig. 2. Export volume of mineral or chemical fertilizers in Ukraine from 2011 to 2019

[Based on (State, 2020a)]

for the period 2011-2019 decreased by $98.5 \%$. The change in the market preferences is primarily due to the non-price factors, the main of which is the change in the consumer requirements.

The application of nitrogen fertilizers, which takes an important place in the systems of agricultural plant fertilization, allows increasing the crop yields and partially decrease the natural soil fertility. Effective use of nitrogen fertilizers is possible only with the simultaneous introduction of other nutrients (phosphorus, potassium, some trace elements, and organic compounds) (Tripolskaja, et al, 2017; Cole, 2017), which can also lead to the agrogenic soil contamination by heavy metals (HM), arsenic, and radioactive elements.

The local companies use imported raw materials for the production of $\mathrm{P}, \mathrm{K}$, and complex fertilizers. Among these materials are the phosphorites from the Middle East and North Africa and potassium chloride from the Republic of Belarus with a high content of heavy metals and radionuclides (Yastrub, et al., 2013).

Ukraine has its phosphate and potassium raw materials, which are currently not developed due to low nutrient content or significant investment. The extraction of apatites from the apatite-ilmenite ore deposits is reasonable only with their joint enrichment. The phosphorite raw materials after enrichment have a low content of $\mathrm{P}_{2} \mathrm{O}_{5}$. They cannot be used for acid decomposition to obtain phosphorus and complex fertilizers (Vakal S., 2018).

The development of complex NPK-fertilizers from foreign phosphate raw materials has allowed ensuring agricultural production with a full range of primary nutrients and reducing the content of $\mathrm{P}_{2} \mathrm{O}_{5}$ and heavy metals. Simultaneously, with increasing fertilizer application rates, the utilization rate of nitrogen decreases, while both absolute and relative loss increases (Table 2) (Malovanyy and Tymchuk., 2012).

Numerous studies confirm that due to the rapid transformation of nitrogen fertilizers in the soil, the nitrogen loss in gaseous form can reach $25 \%$, whereas the vertical and horizontal migration causes pollution of groundwater and surface water with nitrate form. According to Table 2, the soils also have a significant loss of calcium. The following well-known scientists devoted their works to the study of the problems of effective and ecologically safe application of mineral fertilizers:

Table 2. Loss of nutrients from the soil to the environment, when applying high doses of fertilizers, $\mathrm{kg} / \mathrm{ha}$

\begin{tabular}{|c|c|c|c|c|c|c|}
\hline \multirow{2}{*}{ Application of nutrients } & \multicolumn{3}{|c|}{ Loamy soil } & \multicolumn{3}{c|}{ Sandy soil } \\
\cline { 2 - 7 } & $\mathrm{N}$ & $\mathrm{K}_{2} \mathrm{O}$ & $\mathrm{CaO}$ & $\mathrm{N}$ & $\mathrm{K}_{2} \mathrm{O}$ & $\mathrm{CaO}$ \\
\hline No fertilizers & 4.8 & 4.0 & 35.8 & 8.1 & 2.7 & 61.2 \\
\hline $\mathrm{N}_{340} \mathrm{P}_{340} \mathrm{~K}_{300}$ & 27.8 & 23.2 & 180.0 & 72.3 & 29.4 & 24.7 \\
\hline
\end{tabular}


Table 3. Removal of nutrients by crops per 1 centner of product, $\mathrm{kg}$

\begin{tabular}{|c|c|c|c|c|c|c|}
\hline \multirow{2}{*}{\multicolumn{2}{|c|}{ Yield }} & \multicolumn{5}{|c|}{ Crop } \\
\hline & & Wheat & Barley & Corn & Sunflower & Rapeseed \\
\hline \multirow{3}{*}{ Biological } & $\mathrm{N}$ & 2.89 & 2.47 & 2.41 & 4.28 & 6.50 \\
\hline & $P$ & 1.00 & 1.09 & 0.86 & 1.72 & 2.40 \\
\hline & $\mathrm{K}$ & 2.07 & 2.26 & 2.24 & 10.43 & 4.20 \\
\hline \multirow{3}{*}{ Main products } & $\mathrm{N}$ & 2.07 & 1.68 & 1.53 & 2.37 & 4.63 \\
\hline & $P$ & 0.74 & 0.74 & 0.59 & 1.04 & 1.73 \\
\hline & $\mathrm{K}$ & 0.49 & 0.49 & 0.42 & 0.84 & 1.26 \\
\hline \multirow{3}{*}{ By-products } & $\mathrm{N}$ & 0.51 & 0.54 & 0.69 & 0.87 & 0.70 \\
\hline & $P$ & 0.16 & 0.19 & 0.21 & 0.31 & 0.25 \\
\hline & $\mathrm{K}$ & 0.99 & 1.17 & 1.42 & 4.36 & 1.10 \\
\hline \multicolumn{2}{|c|}{$\begin{array}{l}\text { The weighted average ratio } \\
\text { of by-products to the main }\end{array}$} & 1.60 & 1.30 & 1.30 & 2.22 & 2.67 \\
\hline
\end{tabular}

V.I. Gladushko, I.M. Astrelin, M.S. Malovany, L.D. Plyatsuk, B.S. Nosko, G.M. Gospodarenko, A. Ražukas, J.-P. Malingreau, J.C. Cole, M.E. Trenkel, C. Zhi-Feng, X. Zhi-pen and others.

The removal of nutrients from the soil with the crop yield reaches significant values (Table 3 ) (Vakal V., 2019). Thus, the critical requirement for developing new forms of fertilizers should be their minimal impact on the environment with maximum effectiveness for plants.

The aim of the work is the development and implementation of ecologically friendly organomineral fertilizers to improve the environmental safety.

\section{MATERIALS AND RESULTS}

An ecological innovation is to reduce the destructive impact of mineral fertilizers on the environment and increase the effectiveness of their use. As a basis for such innovation, the technology of obtaining complex organo-mineral NPK fertilizers by encapsulating a urea granule with a phosphate-potassium shell with the addition of trace elements and humates was proposed. The main tasks of this shell are the nitrogen and phosphate nutrients release from the granules into the soil following the agrochemical needs of plants and the prevention of soil pollution (Hai-yan, et al., 2018; Trenkel, 2010; Pan, et al., 2016). Applying a fertilizer shell (capsule) to the surface of the granules slows down the transition of nutrients in the terrestrial environment, which increases the rate of assimilation by plants (Malovanyy et al., 2020b).
It should be noted that a significant advantage of this technology is the ability to produce the fertilizers of new generation. Changing the composition of the granule shell, it is capable of providing a high level of customization of fertilizers while reducing the logistics costs that significantly increase the level of their competitiveness in both domestic and foreign markets.

The use of slow-release fertilizers (SRFs) in crop production is considered beneficial due to the reduced risk of environmental nutrient loss. Currently, intensive research is directed towards formulating low-cost, eco-friendly SRFs and evaluating their efficacy on the growth and yield of crops. Due to the high cost of fertilizers, the amounts supplied to the crops should be sufficient and efficient to increase the yields and returns without environmental degradation. This can be achieved by establishing an optimal fertilizer application rate, as defined in both agronomic and economic perspective (Rop, et al.,2019).

Our research has shown that it is unnecessary to use rather expensive powdered ammophos and other phosphates obtained by acid decomposition of apatites or phosphorites as a phosphate component. In our case, both the phosphorite and phosphate-glauconite natural domestic concentrates with the general content of $\mathrm{P}_{2} \mathrm{O}_{5}$ of not more than $15 \%$ are quite effective. The main technological and agrochemical limitation of their application is assimilable $\mathrm{P}_{2} \mathrm{O}_{5}$, not less than $80 \%$. Another important condition is the need to include alkali metal humates as an element that compensates for the partial reduction in soil fertility when growing crops. 
Table 4. Chemical composition of the phosphate-glauconite concentrate

\begin{tabular}{|l|c|}
\hline \multicolumn{1}{|c|}{ Name of indicator and measurement unit } & The result of the analysis \\
\hline Mass fraction of total phosphates in terms of $\mathrm{P}_{2} \mathrm{O}_{5 \text { gen. }} \%$ & 15.00 \\
\hline Mass fraction of assimilable phosphates in terms of $\mathrm{P}_{2} \mathrm{O}_{5 \text { assim. }} \%$ & 13.10 \\
\hline Mass fraction of water, $\%$ & 1.27 \\
\hline
\end{tabular}

Thus, it becomes possible to develop a technology for obtaining organo-mineral complex NPK fertilizer for a basic application. The powdered components agglomeration of phosphate and potassium fertilizers with a small amount of liquid phase (plasticizer) allows forming a phosphate-containing coating with the semi-dry method. This innovation allows organizing the production of such a product at the average enterprise with less capital investment.

Carbamide prills, phosphate-glauconite concentrate, calcium and potassium ballast humates, as well as "Avatar" trace-element chelate complex were used in experimental studies. The indicators of the phosphate-glauconite concentrate of the Novo-Amvrosiivskyi deposit are shown in Table 4.

The dispersed composition of the phosphateglauconite concentrate of the Novo-Amvrosiivskyi deposit is shown in Table 5.

Calcium and potassium ballast humates and kalimag (K-Mg) solutions were used as plasticizers. The use of kalimag as a plasticizer was previously processed by us in the production of phosphoruspotassium fertilizers. Potassium humate is currently widely produced in Ukraine. The choice of calcium humate is justified by the need to introduce an organic component into the composition of the granule, which - in addition to astringent properties - has a positive effect on the content of humus in the soil. Kalimag $\left(46 \% \mathrm{~K}_{2} \mathrm{O}\right)$ was used to enrich the encapsulated fertilizer with nutrient potassium and magnesium. Calcium ballast humate was obtained from

Table 5. Dispersed composition of the phosphateglauconite concentrate

\begin{tabular}{|c|c|}
\hline The fraction of particle size & Mass fraction, $\%$ \\
\hline$>0.4 \mathrm{~mm}$ & 0.85 \\
\hline$>0.315 \mathrm{~mm}$ & 1.27 \\
\hline$>0.28 \mathrm{~mm}$ & 2.54 \\
\hline$>0.2 \mathrm{~mm}$ & 0.56 \\
\hline$>0.1 \mathrm{~mm}$ & 37.88 \\
\hline$>0.063 \mathrm{~mm}$ & 21.83 \\
\hline$<0.063 \mathrm{~mm}$ & 35.07 \\
\hline
\end{tabular}

the lowland peat of the Glukhiv deposit in the Sumy region on a model homogenizer. The chemical composition of calcium humate is shown in Table 6 .

The methods for obtaining granular products are divided by way of implementation (Muralidhar, et. al., 2016; Stahl, 2010; Parikh, 2009), organization of flow (Artyukhov and Sklabinskyi, 2017), instrumentation (Solanki, 2010; Srinivasan, 2010; Saikh, 2013), the use of additional stages (Artyukhova, 2019; Artyukhova, 2020) with different hydrodynamic and thermodynamic conditions but differ in their advantages, disadvantages, and scope (Patel, et. al., 2011; Shanmugam, 2015; Artyukhov and Artyukhova, 2018).

The disc granulators used in this work have found wide application in the granules coating technology (Hoeung, et. al., 2011). The application studies of the phosphate-containing shell on carbamide prills were performed on a laboratory plate granulator with a plate diameter of 0.5 meters. Calcium and potassium humates and previously tested aqueous solution of Kali-mag were used as a plasticizer. The samples of fertilizers were obtained as follows. The powdered phosphate-glauconite concentrate was fed to a plate granulator on carbamide granules with a size of $2-3 \mathrm{~mm}$ and the addition of plasticizer. The encapsulation process took place by the mechanism of agglomeration for 5 minutes. Then the resulting product was sent for drying for 2 hours at a temperature of $65^{\circ} \mathrm{C}$. The composition of the plasticizer and its effect on the properties of the fertilizer shell were

Table 6. Chemical composition of calcium humates

\begin{tabular}{|l|c|}
\hline \multicolumn{1}{|c|}{$\begin{array}{c}\text { Name of indicator and } \\
\text { measurement unit }\end{array}$} & $\begin{array}{c}\text { The result of } \\
\text { the analysis }\end{array}$ \\
\hline $\mathrm{pH}$ (10\% water solution) & 9.0 \\
\hline Mass fraction of water, \% & 89.5 \\
\hline $\begin{array}{l}\text { Mass fraction of humates } \\
\text { (in terms of dry matter), \% }\end{array}$ & 16.9 \\
\hline $\begin{array}{l}\text { Mass fraction of total calcium } \\
\text { (in terms of dry matter), \% }\end{array}$ & 6.0 \\
\hline $\begin{array}{l}\text { Mass fraction of water-soluble calcium } \\
\text { (in terms of dry matter), \% }\end{array}$ & 0.3 \\
\hline $\begin{array}{l}\text { Mass fraction of magnesium } \\
\text { (in terms of dry matter), \% }\end{array}$ & 0.8 \\
\hline $\begin{array}{l}\text { Mass fraction of total potassium } \mathrm{K}_{2} \mathrm{O}, \\
\text { (in terms of dry matter) \% }\end{array}$ & 0.05 \\
\hline
\end{tabular}


Table 7. Composition of produced samples of fertilizers based on carbamide in phosphate shell

\begin{tabular}{|c|c|c|c|c|c|}
\hline \multirow{2}{*}{ No. of sample } & \multicolumn{3}{|c|}{ Composition, \% } & \multirow{2}{*}{ Plasticizer } & Density of granules, \\
\cline { 2 - 5 } & $\mathrm{P}_{2} \mathrm{O}_{5}, \%$ & $\mathrm{~N}, \%$ & $\mathrm{~K}_{2} \mathrm{O}, \%$ & \\
\hline Sample 1 & 7.2 & 23.8 & 0.31 & Calcium humate & 2.10 \\
\hline Sample 2 & 7.13 & 23.6 & 0.21 & Potassium humate & 2.07 \\
\hline Sample 3 & 7.84 & 21.8 & 0.42 & Potassium-magnesium & 2.09 \\
\hline Sample 4 with "Avatar" & 7.4 & 22.8 & 0.21 & Calcium humate & 1.71 \\
\hline
\end{tabular}

varied and studied. In order to improve the nitrogenphosphorus nutrition, increase stress resistance, and productivity of plants, the "Avatar" multicomponent microelement complex in the chelated form was added to the shell composition of the fourth test sample. The physical and chemical studies of the finished product were performed according to the standard methods for mineral fertilizers. The chemical composition of the obtained samples of encapsulated carbamide is presented in Table 7.

On the basis of the requirements for this class of fertilizers, the research was conducted to develop the coating composition, and some plasticizers were selected for further research. The criteria for selecting the plasticizer were its binding properties for agglomeration of the phosphate-glauconite concentrate particles and certain water solubility, which allows forming the membrane structure of the granule coating. The proposed method of the urea granules encapsulation process in a plate granulator allowed us to obtain four samples of complex organo-mineral NPK-fertilizers with plasticizers. The liquid calcium and potassium humates and potassium-magnesium solution were used as plasticizers. The physicochemical studies of the morphology and elemental composition of fertilizer samples were performed by scanning electron microscopy with EDX analysis to assess the quality of the phosphate-containing shell. The elemental composition of granule 1 with a calcium humate as a plasticizer is presented in Figure 3.

The structure of the shell and core were studied to determine the optimal components of the plasticizer (Table 7) and the technological parameters of the granules shell formation.

The analysis of the spectra in Figure 3 shows that the penetration of nitrogen from the granule core into the structure of the phosphate-containing shell is minimal. The spectrum 15 of granule's core is the characteristic of the chemical composition of carbamide. Thus, it is possible to conclude the physicochemical nature of the b)

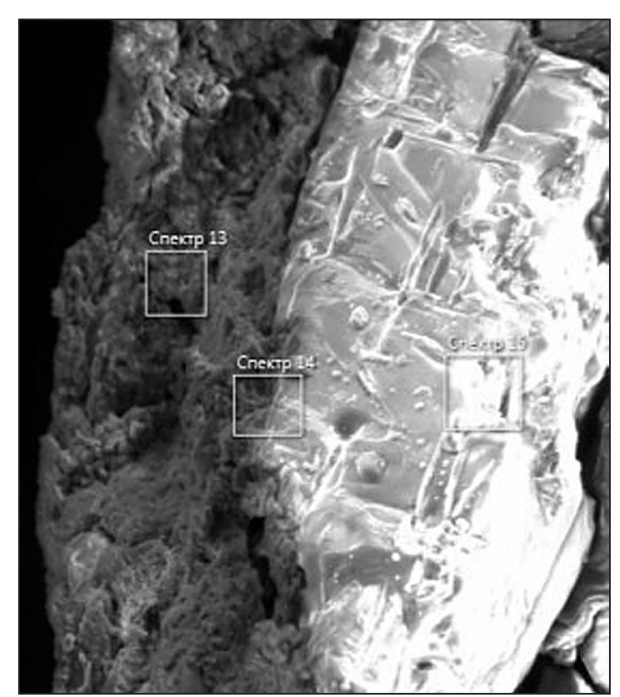

a)

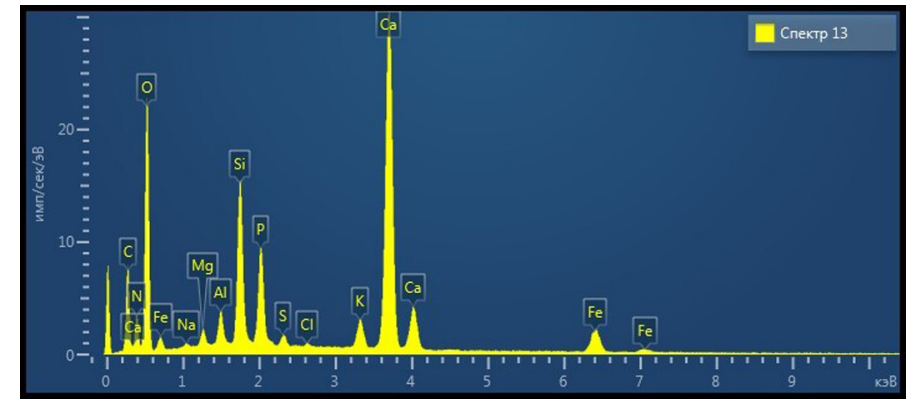

c)

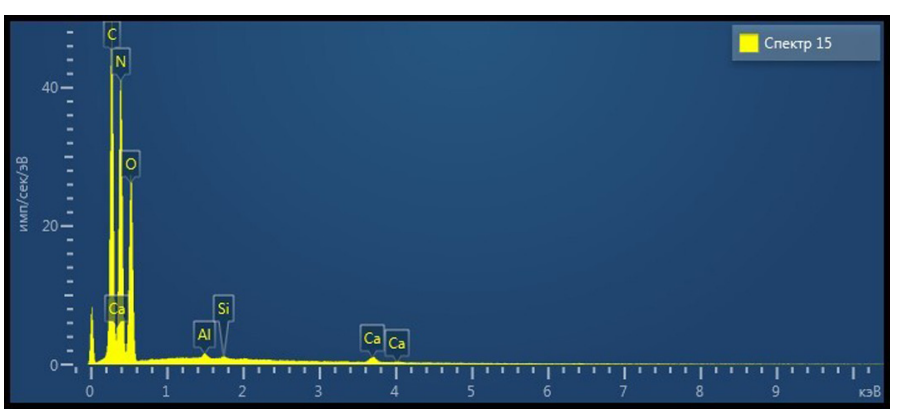

Fig. 3. Distribution of elements in granule 1 cross-section: a) Spectrum 13 shows element composition in granule's shell, b) general view of granule cross-section with places of analysis, c) Spectrum 15 shows element composition in granule's core. 
fixation of the phosphate-containing shell on the carbamide granules.

The phosphate-potassium shell itself acts as a membrane that retards the rate of carbamide dissolution, and as a nutrient with a slower solubility. On the basis of the performed studies, the most technologically advanced plasticizer - calcium humate, which increases the strength of the capsulated granules and improves soil fertility, has been determined.

A preliminary assessment of the market prospects for such an innovation shows a high level of market attractiveness for all market participants: producers, consumers, and society.

Given that in the general structure of the land fund of Ukraine the area of agricultural lands is 41.5 million hectares (Shkola, et. al., 2016) and only about $40 \%$ of these areas are treated annually with mineral fertilizers, as well as the evergrowing demand for mineral fertilizers (Fig. 4), which has almost doubled (excluding the occupied territories) compared to 2011, the market potential for the new generation mineral fertilizers is $90 \%$. This indicates a high probability that the innovation will succeed in the market.

Moreover, it should be noted that this measure tends to be higher, given that the statistical data are provided on the enterprises that own and use 200 hectares of agricultural land and/or more than 5 hectares of planted areas for open-field vegetables and/or for greenhouse vegetables and/ or for melons (State, 2020b).
In addition, the complete replacement of the existing non-organic fertilizers with the environmentally friendly innovative fertilizers will increase the level of environmental safety of the country or region, thereby approaching to its equilibrium or natural level (Prokopenko and Shkola, 2012).

According to preliminary estimates, the socio-ecological and economic efficiency of new fertilizers is also high. The expected socio-ecological and economic effect from production and consumption for all stakeholders is about 6 billion USD a year. Compared to the method of obtaining granules from solutions, the semi-dry method shows $70 \%$ less energy consumption and thermal pollution of the environment according to an approximate calculation of the ecological and economic efficiency of the production and use of fertilizers. Simultaneously, the consumption of natural gas and, accordingly, the dust and gas emissions during the production of fertilizers with the semi-dry method (applying a phosphatecontaining coating) can be reduced by three times. The reduction of the dust and gas emissions, estimated through the emissions of $\mathrm{CO}_{2}$ greenhouse gases with this acid-free method, is 67 USD per 1 ton of fertilizer (Vakal S., 2018).

The decrease in the nitrous oxide emissions from soils in terms of $\mathrm{CO}_{2}$ is 1.24 tons $\mathrm{CO}_{2}$ from 1 hectare of arable land or in monetary terms is about 35 USD per 1 ha is possible due to the decrease in the gaseous nitrogen losses in

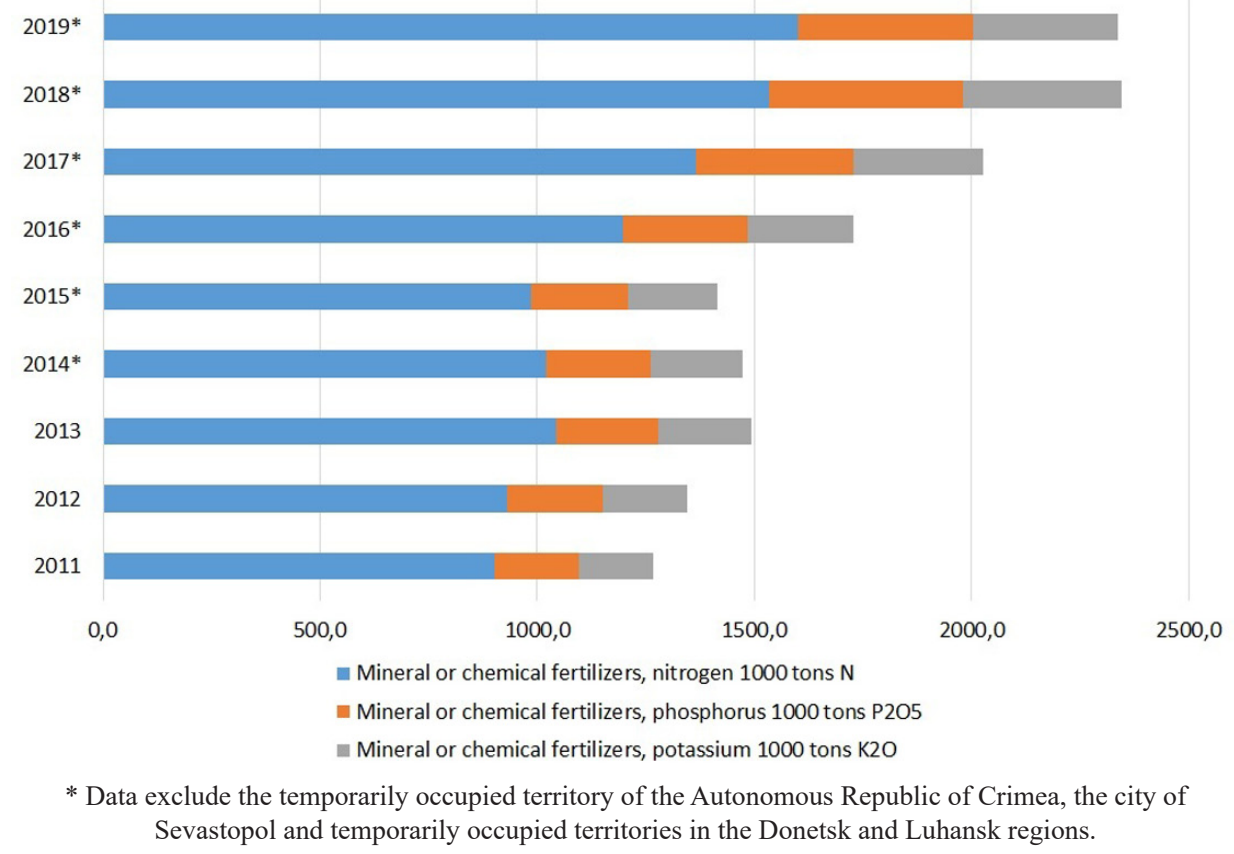

Fig. 4. Use of inorganic fertilizers for the harvest of agricultural crops in Ukraine [Based on (State, 2020b)] 
agriculture from the carbamide capsulated with an organic-mineral phosphate-containing shell (Vakal V., 2019). These calculations will be necessary for the near future due to the requirements of environmental services to reduce the greenhouse gas emissions from arable land.

The efficiency of encapsulated organic-mineral fertilizer production $\left(\mathrm{K}_{\mathrm{e}}\right)$ can be assessed in general by the environmental factor (Vakal S., 2018), which is defined as the difference between the cost of raw materials, which can be taken as 1 , and the cost of waste generated during the processing of raw materials (B). Fluctuations in the value of $K_{e}$ in the range from 0.9 to 1 indicate high production efficiency and low levels of environmental pollution. A semiquantitative comparative analysis of the acid methods of complex mineral fertilizers obtaining with the release of a significant amount of phosphogypsum as production waste and the production of such fertilizers by the acid-free process with a loss of dust of not more than $10 \%$, allows minimizing " $\mathrm{B}$ " indicator and increasing environmental friendliness. Therefore, in terms of environmental safety, such fertilizers can be classified as environmentally safe.

Slow-controlled-release (CRFs) fertilizers obtained by means of the granule-shell technology could be ideal and popular fertilizers to improve the nitrogen use efficiency and reduce the environmental hazards owing to their following characteristics: a) one single application supplies the necessary amount of nutrients for plant growth; b) higher crop output can be achieved with lower fertilizer input; c) they cause minimum adverse effects on the soil, water, and atmosphere. Due to the advantages of CRFs, they have been recognized as one of the most promising fertilizers that can be applied to agricultural systems. The main ideas that should be included in the proposal for the development of new brands of fertilizers:

- More complete use of the fertilizer nutrients while reducing its unproductive losses;

- Complex composition of fertilizer, consisting of essential nutrients and nutrients for the plant for the entire growing season;

- Necessary condition - the creation of an organo-mineral complex;

- Minimal impact on the environment during the production and application of fertilizers;

- Minimization of the production costs in the production and use of fertilizers.

\section{CONCLUSIONS}

Thus, based on the requirements for perspective types of fertilizers, and following the performed studies, it can be concluded that the development of complex-mixed organic-mineral encapsulated forms of carbamide for the main application is promising. This technical solution is justified by the possibility of obtaining not only encapsulated carbamide granules with the introduction of various modifiers into the shell but also, in general, the NPK fertilizers by means of the semi-dry method, which is economically and environmentally effective in their production and use.

\section{Acknowledgements}

This research work had been supported by Ministry of Science and Education of Ukraine under the project "Process of formation of the novel ecologically safe fertilizers with prolonged action based on the phosphorite deposits raw materials" Grant number 0120U102003 and Cultural and Educational Grant Agency of the Slovak Republic (KEGA), project No. KEGA 002TnUAD-4/2019.

\section{REFERENCES}

1. Artyukhov A., Artyukhova N. 2018. Utilization of dust and ammonia from exhaust gases: new solutions for dryers with different types of fluidized bed. Journal of Environmental Health Science and Engineering, 16, 193-204. https://doi.org/10.1007/ s40201-018-0307-5

2. Artyukhov A.E., Sklabinskyi V.I. 2017. Investigation of the temperature field of coolant in the installations for obtaining $3 \mathrm{~d}$ nanostructured porous surface layer on the granules of ammonium nitrate. Journal of Nano- and Electronic Physics, 9 (1), 01015-1-01015-4. https://doi.org/10.21272/ jnep.9(1).01015

3. Artyukhova N.O. 2020. Morphological Features of the Nanoporous Structure in the Ammonium Nitrate Granules at the Final Drying Stage in Multistage Devices. Journal of Nano- and Electronic Physics, 12 (4), 04036-1-04036-6. https://doi.org/10.21272/ jnep.12(4).04036

4. Artyukhova N.O., Krmela J. 2019. Nanoporous Structure of the Ammonium Nitrate Granules at the Final Drying: The Effect of the Dryer Operation Mode. Journal of Nano- and Electronic Physics, 11 (4), 04006-1-04006-4. https://doi.org/10.21272/ jnep.11(4).04006. 
5. Assessing global land use: balancing consumption and sustainable production. 2014. UN report. Davos, Switzerland, 24 01.2014, 6.

6. Baluk S.A., Medvediev V.V., Miroshnychenko M.M., Skrylnyk E.V., Tymchenko D.O., Fatieiev A.I., Khrystenko A.O., Tsapko Yu.L. 2012. Ecological condition of soils (in Ukrainian). Ukrainian Geographical Journal, 2, 38-42.

7. Brauweiler, H.C., Shkola, V., Markova O. 2017. Economic and legal mechanisms of waste management in Ukraine. Marketing and Management of Innovations, 2, 359-368. http://doi.org/10.21272/ mmi.2017.2-33.

8. Hoeung P., Bindar Y., Senda S. P. 2011. Development of granular urea-zeolite slow release fertilizer using inclined pan granulator. Jurnal Teknik Kimia Indonesia, 10 (2), 102-111. https://doi.org/10.5614/ JTKI.2011.10.2.6

9. Cole J.C., Smith M.W., Penn C.J., Cheary B.S., Conaghan K.J. 2016. Nitrogen, phosphorus, calcium, and magnesium applied individually or as a slow release or controlled release fertilizer increase growth and yield and affect macronutrient and micronutrient concentration and content of field-grown tomato plants. Scientia Horticulturae, 211, 420-430. https://doi.org/10.1016/j.scienta.2016.09.028

10. Rop K., Karuku G.N., Mbui D., Njomo N., Michira I. 2019. Evaluating the effects of formulated nanoNPK slow release fertilizercomposite on the performance and yield of maize, kale and capsicum. Annals of Agricultural Sciences, 64(1), 9-19. https:// doi.org/10.1016/j.aoas.2019.05.010

11. Malovanyy M., Ilyash O., Povzun O., Stepanets O., Serga T., Gubar O., Serdyuk V. 2020a. Environmental and resource evaluation of smelter slag. Environmental problems, 5(1), 19-29. https://doi. org/10.12911/22998993/116339

12. Malovanyy M., Shandrovych V., Malovanyy A., Polyuzhyn I. 2016. Comparative Analysis of the Effectiveness of Regulation of Aeration Depending on the Quantitative Characteristics of Treated Sewage Water. Journal of Chemistry, Article ID 6874806, 9. https://doi.org/10.1155/2016/6874806.

13. Malovanyy M.S., Synelnikov S.D, Nagurskiy O.A, Soloviy K.M., Tymchuk I.S. 2020b. Utilization of sorted secondary PET waste - raw materials in the context of sustainable development of the modern city. IOP Conf. Series: Materials Science and Engineering 907 (2020) 012067 IOP Publishing. https:// doi.org/10.1088/1757-899X/907/1/012067

14. Malovanyi M.S., Tymchuk I.S. 2012. The negative impact of mineral fertilizers on the agroecosystem and its minimization by the method of encapsulation of fertilizers (in Ukrainian). Scientific Bulletin of Lviv National University of Veterinary Medicine and Biotechnology named after Gzhytsky, 14, 2(3), 116-123.
15. Muralidhar P., Bhargav E., Sowmya C. 2016. Novel techniques of granulation: a review. International Research Journal of Pharmacy, 7(10), 8-13. https:// doi.org/10.7897/2230-8407.0710114

16. Pan Pan, Jiang Hui-Min, Zhang Jian-Feng, Yang Jun-Cheng, Li Shu-Shan, Liu Lian, Zhang Shui-Qin, Lei Mei. 2016. Shifts in soil bacterial communities induced by the controlled-release fertilizer coatings. Journal of Integrative Agriculture, 15(12), 2855-2864. https://doi.org/10.1016/S2095-3119(15)61309-0

17. Parikh D. 2009. Handbook of Pharmaceutical Granulation Technology, 3. Informa Healthcare, 676 p. https://doi.org/10.3109/9781616310035

18. Patel P., Telange D., Sharma N. 2011. Comparison of Different Granulation Techniques for Lactose Monohydrate. International Journal of Pharmaceutical Sciences and Drug Research, 3, 222-225.

19. Popovych V., Stepova K., Prydatko O. 2018. Environmental hazard of Novoyavorivsk municipal landfill. In MATEC: Web of Conferences 247, 00025. FESE 2018. https://doi.org/10.1051/ matecconf/201824700025.

20. Prokopenko, O.V., Shkola, V.Yu. 2012. Controlling of the ecological and economic enterprise security on the bases of ecomarketing. Marketing and Management of Innovations, 4, 337-346.

21. Saikh M.A. 2013. A technical note on granulation technology: a way to optimise granules. International Journal of Pharmaceutical Sciences Review and Research, 4, 55-67.

22. Solanki H.K., Basuri T., Thakkar J.H., Patel C.A. 2010. Recent advances in granulation technology. International Journal of Pharmaceutical Sciences Review and Research, 5(3), 48-54.

23. Srinivasan S. 2015. Granulation techniques and technologies: recent progresses. Bioimpacts, 5(1), 55-63. https://doi.org/10.15171/bi.2015.04.

24. Shanmugam S. 2015. Granulation techniques and technologies: recent progresses. Bioimpacts, 5(1), 55-63. https://doi.org/10.15171/bi.2015.04

25. Stahl H. 2010. Comparing Granulation Methods. Hürth: GEA Pharma Systems, p. 10.

26. State Fiscal Service of Ukraine. 2020a. The total volume of imports and exports in terms of product items by codes of Ukrainian classification of goods of foreign economic activity.

27. State Statistics Service of Ukraine. 2020b. Use of inorganic and organic fertilizers (1990-2019).

28. Trenkel, M.E. 2010. Slow- and controlled-release and stabilized fertilizers: an option for enhancing nutrient use efficiency in agriculture. International Fertilizer Industry Association (IFA).

29. Tripolskaja L., Ražukas A., Šidlauskas G., Verbylienė I. 2017. Effect of fertilizers with different chemical composition on crop yield, nitrogen 
uptake and leaching in a sandy loam Luvisol. Zemdirbyste-Agriculture, 104 (3), 203. https://doi. org/10.13080/z-a.2017.104.026

30. Vakal S.V. 2018. Scientific and theoretical basis for the creation of new environmentally safe technological processes of phosphorus fertilizers production (in Ukrainian). Dr. Sc. Thesis, Sume State University, Sumy.

31. Vakal V.S. 2019. Reduction the technogenic load on the environment when using the nitrogen fertilizers with phosphorus-containing coating. $\mathrm{Ph} \mathrm{D}$. Thesis, Sumy State University, Sumy.

32. Voloshchuk M. 2017. Soil degradation is a global environmental problem. Bulletin of Lviv University. The geographical series, 51, 63-70.
33. Wei Hai-Yan, Chen Zhi-Feng, Xing Zhi-Peng, Zhou Lei, Liu Qiu-Yuan, Zhang Zhen-Zhen, Jiang Yan, $\mathrm{Hu}$ Ya-Jie, Zhu Jin-Yan, Cui Pei-Yuan, Dai QiGen, Zhang Hong-cheng. 2018. Effects of slow or controlled release fertilizer types and fertilization modes on yield and quality of rice. Journal of Integrative Agriculture, 17 (10), 2222-2234.

34. Yastrub T.O., Kirsenko V.V., Vakal S.V., Korshun M.M. 2013. The problem of heavy metals in the production and use of phosphorus-containing mineral fertilizers (by example of cadmium, lead, arsenic). Labor medicine, 3, 8-11.

35. Shkola V.Yu., Domashenko M.D., Kuchmiyov A.V., Novak K.S. 2016. Fundamentals of the Ukrainian land fund management. Marketing and Management of Innovations, 2, 235-345. 